\title{
The Identity Construction of Woman Politician on Facebook
}

\author{
Nurannafi FSM \\ Department of Communication \\ Dr. Soetomo University \\ Surabaya, Indonesia \\ Padjadjaran University \\ Bandung, Indonesia \\ snurannafi@unitomo.ac.id
}

\author{
Rd. Funny Elita, Edwin Rizal, Slamet Miulyana \\ Communication Lecturer \\ Padjadjaran University \\ Bandung, Indonesia
}

\begin{abstract}
In 2014, According to Association of Internet Service Providers Indonesia's data, internet users in Indonesia will reach 107 million in 2014. This study looks at how Facebook as a medium of political communication is used well by women legislators in constructing their identity as the representatives of people. Facebook enables female legislators to compose personal messages and spread mass messages quickly to reach the wider audience. It provides opportunities for Facebook users to think, behave, or act, without any significant control, except their own self-awareness. If in everyday life women politicians are bound by many values and rules in society, then how do social users see and construct themselves on Facebook? This research used the qualitative method applying case study approach. Data were collected through in deep inter-views, observations and literature studies. Research subjects are female legislators of Surabaya city who have the characteristics of Facebook as well as active users, understand the problems, and can be trusted. The results showed that female legislators had different motive in using Facebook before and after being elected as a woman legislator. The factors that distinguish are: the motive to be a female politician and the encouragement of the political party. The lack of female legislators in Surabaya City that make Facebook as a medium of politic, but use it as a medium of communication, medium of existence, medium of self-image. This implies on the lack of women legislators in realizing the importance of creating and keeping identity well as representatives of the people. In fact, Identity online construction is done through a choice of features on Facebook used, such as photos, posts, and verbal/ non-verbal language select-ed and used.
\end{abstract}

Keywords-meaning; personality; political media online; female; legis-lator

\section{INTRODUCTION}

The development of information technology and communication has changed the way individual interact with other individuals. The internet has become a new digital media space that creates a new cultural space. Therefore, there is a cultural shifting, from the traditional into digital media culture. By the time of the 2000 presidential election, candidate web sites had become a common campaign tool, which led some to proclaim 2000 as the "first Internet election" [1]. The use of these digital media clearly surpassed the use if party web sites and different social media for political purpose [2]. In 2008 , newer online line tools such as social networking and microblogging gained popularity and were effectively used by the Obama campaign to mobilize and organize supporters [3]. The existence of social media has changed the way people access digital technology. Likewise, politic culture increases the access and the number of users of social media. It is potential for political actors in conducting political communication and creating a good image in society, especially among young voters. Based on previous research on "political use" of the internet, an approach we find to be more indicative toward the mechanisms through new media that engages the society.

Iinformation exchanged over the internet fosters civic engagement, trust, and life contentment in younger generation [4]. Meanwhile, social recreation on the internet is negatively correlated with trust and life contentment. One of the most influencing social media in Indonesia is Facebook. As of winter 2011, Face-book is currently considered the largest online social network with over 800 million active users, surpassing other online social networks such as Myspace, Friendster, and Bebo. Facebook is an online medium that lets users interact with each other by sharing information about themselves via personal pro-files [5].

Regarding to that situation, it is important to understand female legislators' thoughts, attitudes, and acts related to Facebook. Personally, an individual has the freedom and opportunity to produce message on Facebook including about his/her identity. If in everyday life women politicians are bound by many values and rules in society, then how do social users see and construct themselves on Facebook?

\section{RESEARCH METHOD}

This research uses qualitative approach with descriptive case study method. Data were collected through interviews, case studies and literature studies. Informant at this time is a member of women legislator in Surabaya. 


\section{RESULT AND DISCUSSION}

Referring to the focus of research that led to this study, the analysis refers to the question the researcher aims.

\section{A. Facebook operational}

The use of Facebook by female legislators is divided into two impulsions, the past and the future. It is because the use of Facebook prior the legislation role, and then reconstructed during legislation period. Facebook usage is usually performed due to some reasons. The first reason is external impulsion. It comes from environmental influence, usually the influence of friends, families, or colleges who are Facebook user. The second reason is internal impulsion. It comes within themselves seeking freedom and happiness outside their daily routines as a housewife or working. Facebook has become the "me time" medium for woman. Hand phone and laptop usage is also influencing Facebook usage's intensity.

Those two reasons have become the main object of the female legislator in Surabaya using Facebook. As being exposed by Schutz, human being has certain aim which is called "the other in motive" [6]. The cause of the motive is "the genuine because-motive" [6]. The motives are the reasons why human being doing something.

Being a member of the women legislators hold big responsibility in keeping the mandate as the representative of people. Their attitude becomes the center of attention in the community. Therefore, some members of the legislator reconstruct their image, one of the way is using Facebook. It relates to their duties as the representative of the people, as part of a political party and as part of his constituency. Some legislators choose not to be too active using Facebook, but some choose to stay active and manage to use their Facebook. The use of Facebook is influenced by several things such as political impulsion and influence of political culture, which is part of the political media. The ease of internet access, the demand of relationship maintenance and communication with the community in order to create a good reputation as a representative of the people also indeed affects the members of the legislator in using Facebook.

\section{B. The Significant of Facebook}

Members of the legislator interpreted the existence of Facebook as:

- Facebook is interpreted as a keep-in-touch media for women legislators. Facebook can connect to different levels of society. Therefore, it can be functioned as a means of interaction and means of information exchange without being limited by distance and time. By using the Facebook account, the politicians expect to exchange information that is interactive to the community. The community can also directly monitor the activities of women legislators. Through direct broadcast media on Facebook, woman legislators have more intense communication with the community through group participants that are made in Facebook. From Facebook also, the members of the legislator can explore the problems that exist in the community quickly. They can recognize and quickly find solutions. In a broader platform, not only with the community itself, women legislator members can build friendship with several colleagues. Relationships that had been interrupted can be re-established through Facebook.

- Facebook as a means of existence and selfactualization. Facebook has becoming a place for women legislators to introduce themselves while at the same time influencing netizens. Facebook becomes the political stage of women legislators. Associated with freedom and fun, Facebook is interpreted as a medium that gives pleasure to its users, releasing its users from cultural rules. Therefore, Facebook is interpreted as an arena to embarrass or get a response or appreciation from other users. Some politicians will know whether they are liked, hated and how much receive love. It is shown by "like" emoticons, but it can also be show how much they are hated.

- Facebook as a medium of self-image. As a media selfimage, Facebook can be served as a branding media for women legislators to be able to strengthen their position as a representative of the people. They deserve support and trust from the community. Facebook provides the widest opportunity for its users to present themselves to netizens.

\section{The Interpretation Diversity about the Identity of Social Media Users}

The meaning of identity that women legislators want to build in Facebook media are:

- Members of the legislator interpret themselves on Facebook as a representative of the people who are responsible for his mandate as a representative of the people. This is illustrated by posting some of his activities on Facebook relating to constituents, parties and the public, such as: activities of visiting selected areas, joint activities of SMEs, meetings with executive bodies, etc. Facebook becomes a political platform for women legislators to be able to show every activity that they do as representatives of the people. The goal is to create a good self-image as a representative of the people by establishing closeness with the community. Goffman stated that three areas for actors when performing themselves in front of audiences are front, back, and outside the stage. Contemporary upon the official position of the team is visible in their front stage presentation, in back stage, the impression in knowingly contradicted as a matter of course, indicating the more truthful type of performance $(1959 ; 112)$. Associated with the political stage as presented by Goffman, then Facebook serves as a media of politics image. Every female legislator member can build their image to be liked by netizens (community) and trusted as people's representatives. In addition, posting activities can also perform sharing, publication of works, forming a community. The selected regional community is very helpful and facilitates legislator members during their period. Some politicians interpret social media 
Facebook as a very effective means to improve communication competence.

- Members of the legislator also interpret themselves as people who have freedom, not a representative of the people, not making Facebook as a political stage. It is a medium to express the other side of their selves as a human in general. Information posted in the form of traveling, social gathering, gathering with family or old friends.

- Different to other women legislative members, they want to be interpreted as a person who loves her family, so that her posts are in the form of family pictures and cooking food for the family. They post articles about his little family. The diversity of meaning about the existence of Facebook for its users relates to herself, her family, her studies, her hobbies, her community and her work. Some informants assume that his identity on Facebook is relatively close to real-world identity. With regard to individual freedom of expression, some female legislators interpret Facebook as a tool for expressing themselves, self-presentation. A place for them to escape from the bondage of values or cultural norms because with Facebook members of the legislator can express in accordance with what her heart desires. There is another side of women legislator members who want to be exposed to the public. According to them, this is their form of honesty and openness of a politician. The informant confessed that she sometimes felt upset and wanted to express her feelings for every problem she faced in Facebook media. Feeling or anxiety can be expelled without fear of damaging its image as a representative of the people. But instead, being a representative of the people limits women legislators in hanging out in the media Facebook. Nevertheless, the informant feels satisfied when expressing her feelings and thoughts regardless her reputation as a representative of the people. This is because of the saturation of every legislator member affect them to do dramatugi because of her duty as a representative of the people. When human interacts with her neighbour, she wants to manage the impression she hopes to grow on others for her. For that, every person does a "show" for others. Life is like a theater and actors are the players [7].This is also contradictory to some sources who revealed that the act of using Facebook could damage its reputation so she chose to stop using it. This is because women legislators do not want to be known more deeply by the public. Limiting herself in public so that she does not need to thinking about managing her image.

\section{Identity Construction through Social Media}

- Construction of the identity of female legislators in Facebook can be viewed from the uploaded photos, whether it is in the form of self-image, or self with friends, family, characters, as well as any posts made or referred or commented on, quotes taken, links accessed, places visited, and activities undertaken or followed by women legislators. In Facebook, there are also some supporting features in the form of symbols, stickers and also GIF that can represent the emotions or thoughts of the source in communicating. A communication medium is used as an intermediary tool of social facts in which cannot be separated from the construction of reality or social construction. Then the construction of reality or social construction itself cannot be released by the use of symbols. The symbol of meaningful and articulated sounds (produced by the utterances), the arbitrary (conventional) and the conventional are used as a means of communicating by a group of humans to create feelings and thoughts that are called words or languages [8].

- Construction of identity through Facebook is done by female legislators through various forms, using either verbal or nonverbal languages. Posts can construct the identity of a Facebook user. Through writing in the form of status, comments, publishing stories of each activity used, sharing articles or tips are considered important by members of the female legislator. Identity construction process on Facebook for female legislators is strongly influenced by the interaction between legislator members toward the society (netizen). It can be explained also with the theory of symbolic interaction. This theory also explains when humans interact with each other, they share the meanings for certain actions for a certain period of time. George herbet mead is seen as a builder of symbolic interaction that teaches about the meaning that arises as a result of interaction between humans both verbally and nonverbally. Through actions and responses that occur, it gives meaning in action or sentence. According to symbolic interaction, individuals interact with other individuals to produce a certain idea of a self [9].

- Construction of identity on Facebook can also be formed from many and varied friendlist (owned by informants). Similarly the activity of 'add friend' made by the speakers in Facebook she uses. Referring to the acknowledgment of sources, it can be said that Facebook can be a tool of self-construction as users desired. Word selection, uploaded images, usergenerated comments can estimate the built-in impressions or meanings about themselves. They are information messages entered or not included in the profile, exposure to status updates including status dominance in terms of the roles of each informant, photo, the interest of choosing a profile photo, significance in entering the relationship status, the authority to remove (untagging) inappropriate or disturbing photographs, motif to update status, the selfrepresentation of the majority. They are described as a pleasant personal figure, both in socializing, and having a friendship and life environment. This means that informants understand that Facebook can be a place to form identity as she wants. The description or meaning can be better understood from the following phrase, who accesses her account so that it controls of the construction process she builds. Informal as a human also seems to understand. There are differences in the 
boundaries of individual values, groups or environments, as from the following expression; In other words, it can be interpreted the user's social identity is basically no single, but depending on the context and the role chosen.

\section{CONCLUSION}

Based on the analysis conducted on the collected research data and refer to the research question, it can be concluded as the following points:

- The use of Facebook by legislator members is done before becoming a legislator member and reconstruct it after becoming a member of the legislator. External factors surrounding the environment and the internal impulsion of the members of the legislator itself take time for themselves.

- Facebook is interpreted as keep-in-touch media, a media of one's existence, and also as media of selfimage.

- The diversity of identity interpretation among female legislators such as wanting to be interpreted as the representative of the people whom is trusted ans as people who have freedom and who love family and friends.

- Construction of legislator member's identity in Facebook can be seen through: some photos, uploaded posts, verbal and nonverbal languages used and the choices of friendship and choices of Facebook features used.

\section{REFERENCES}

[1] Foot, K., and Schneider, S. M. "Web campaigning". Cambridge, MA: MIT Press 2006.

[2] Dimitrova, D. V., Shehata, A., Strömbäck, J., and Nord, L. W. "The effects of digital media on political knowledge and participation in election campaigns: Evidence from panel data". Communication Research, 41(1), 95-118. 2014.

[3] Hendricks, J. A., and Denton, R. E. "Communicator-In-Chief: How Barack Obama used new media technology to win the White House". Lanham, MD: Lexington. 2010.

[4] Shah, D. V., Kwak, N., and Holbert, R. L. ““Connecting” and "disconnecting" with civic life: Patterns of Internet use and the production of social capital". Political Communication, 18, 141-162. 2001.

[5] Conroy, Jessica T and Guerrero, Mario. "Facebook and political engagement: A study of online political group membership and offline political engagement". Computers in Human Behavior, vol 8, 15351536. 2012.

[6] Shutz, Alfred, "the phenomenology of the social Word, London and Edinburg", 1972.

[7] Mulyana, Deddy, "Metode Penelitian Kualitatif", Bandung, Rosdakarya. 2003.

[8] Maryani, Eni and Arifin, S. Hadi, "identity through social media". Journal of Communication Studies, Vol. 1 No. 1, 2012.

[9] Morissan,. “Teori komunikasi”, jakarta: Kencana. 2014. 